The Catholic University of America, Columbus School of Law

CUA Law Scholarship Repository

2016

\title{
Ecclesiastical Liberty on the Eve of the Reformation
}

Kenneth Pennington

The Catholic University of America, Columbus School of Law

Follow this and additional works at: https://scholarship.law.edu/scholar

Part of the History of Religion Commons, and the Medieval History Commons

\section{Recommended Citation}

Kenneth Pennington, Ecclesiastical Liberty on the Eve of the Reformation, 33 BULL. MEDIEVAL CANON L. 185 (2016).

This Article is brought to you for free and open access by the Faculty Scholarship at CUA Law Scholarship Repository. It has been accepted for inclusion in Scholarly Articles and Other Contributions by an authorized administrator of CUA Law Scholarship Repository. For more information, please contact edinger@law.edu. 


\section{Ecclesiastical Liberty on the Eve of the Reformation}

\section{Kenneth Pennington}

For the five centuries after Pope Gregory VII put 'libertas ecclesiae' in the center of the debates over the relationship of the Church to secular power and authority, much of the conflict within the Christian world revolved around one issue: what is the proper legal relationship between the ecclesiastical and secular institutions. The question that Gregory posed was 'could laymen have any jurisdiction or authority within the Church?'1 By the thirteenth century the focus had shifted from the big issue of 'Church and State' to the relationship between the clergy and the laity. The terminology also changed. 'Libertas ecclesiastica' replaced 'libertas ecclesiae' in the writings of medieval and early modern jurists .

The ramifications of this change have not yet been studied. I can make a few preliminary remarks about this intriguing development in terminology. Both terms can be traced back to the patristic age. Saint Hilary of Poitiers (Hilarius Pictaviensis) seems to have been the first to use 'libertas ecclesiae' in his commentary on the Psalms. ${ }^{2}$ Pope Leo the Great was the first to write about 'libertas ecclesiastica' in a letter to Bishop Leo Anatolio about the difficulties in Alexandria at the time of the death of the Emperor Marcianus. ${ }^{3}$ 'Libertas ecclesiae' was, however, the preferred phrase in the early Middle Ages. In the twelfth century, the Father of Canon Law, Gratian, did not include any canons with the phrase 'libertas ecclesiae'. He did include one canon with the phrase

\footnotetext{
${ }^{1}$ Brigitte Szabó-Bechstein, 'Libertas ecclesiae vom 12. bis zur Mitte des 13. Jahrhunders: Verbreitung und Wandel des Begriffs seit seiner Prägung durch Gregor VII.' Die Abendländische Freiheit vom 10. bis zum 14. Jahrhundert: Der Wirkungszusammenhang von Idee und Wirklichkeit im europäischen Vergleich, ed. Johannes Fried (Vorträge und Forschungen 39; Sigmaringen 1991) 147-175.

${ }^{2}$ PL 9.333.

${ }^{3}$ PL 54.1115.
} 
'libertas ecclesiastica'. 4 'Libertas ecclesiae' appears in only a handful of decretals included in the collections of canon law after Gratian. ${ }^{5}$ With his emphasis on papal monarchy and the importance of the Roman church, Pope Innocent III introduced 'libertas Romanae ecclesiae' into a decretal, and the phrase was repeated by popes Nicholas III and Boniface VIII in their decretals. $^{6}$

If one judges only by the texts in the books of law that were taught in the schools and used in the courts, 'Libertas ecclesiastica' supplanted 'libertas ecclesiae' after the twelfth century. The decretal collections from Innocent III's pontificate and after pullulate with 'libertas ecclesiastica,' although Raymond de Peñafort excised some of the passages containing the phrase in his editorial work on the Decretals of Gregory IX. ${ }^{7}$ Linguistic usages and evolutions over time may not be explainable but are intriguing.

Consequently, in the centuries before the Fifth Lateran Council 'libertas ecclesiastica' had become the touchstone defining the relationship between the clergy and the laity. Pope Innocent III embraced the term early in his pontificate. In 1198 Innocent's curia rendered a decision, Magnae devotionis, that gave a different spin on the issue of ecclesiastical liberty. ${ }^{8}$ Magnae devotionis became a key text in canonical jurisprudence for establishing the pope's prerogative to commute crusading vows. That papal right had nothing to do with ecclesiastical liberty. Although papal power became the decretal's calling card, a bishop's duty to defend the liberty of his church was just as significant. Garnerius, bishop of Troyes, had had a problem. His church was being afflicted by grave but unspecified difficulties that damaged the

${ }^{4}$ D. 25 c. 1 ; the 'correctores Romanae' changed 'ecclesiastica' to 'ecclesia' for reasons that are not clear.

5 X 2.27.20 (1199) but in the 'partes decisae'of Raymond de Peñafort and consequently unknown to later canonists and VI 5.11.7, in Friedberg's footnote. ${ }^{6}$ X 5.33.12, VI 1.6.17, 5.7.10, 5.12.2.

${ }^{7}$ The decretals that Raymond shortened and cut out 'libertas ecclesiastica' are: $\mathrm{X}$ 2.1.21, 2.28.25; it was also cut from VI 1.8.2. Raymond cut 'libertas ecclesiae' from X 2.27.20.

83 Comp. 3.26.2. (X 3.34.7) (1198). 
ecclesiastical liberty of his church. He decided that Henry II of Champagne, recently elected the king of Jerusalem, was, as his temporal lord, the only person to whom he could turn. He and some of his clerics made a remarkable decision. They took a vow of pilgrimage to go to the Holy Land and implore Henry to help protect the church at Troyes. When he reached Piacenza, Garnerius learned that Henry had died. The main purpose of the pilgrimage disappeared. Garnerius asked Innocent III to commute their vows. ${ }^{9}$ After much complicated argumentation that would live on in the jurisprudence governing vows and other decisions by corporations, Innocent granted Garnerius and his clerics a commutation of their vows. ${ }^{10}$ Innocent never detailed which rights of the church of Troyes were being threatened nor how they were endangered nor by whom. Nevertheless, the decretal remained a key text that obligated bishops to petition secular rulers to protect diocesan ecclesiastical liberties and rights for centuries. ${ }^{11}$

At the end of his pontificate, Innocent and the Fourth Lateran Council promulgated two canons whose contents were based on the principle of ecclesiastical liberty. In Sicut volumus, canon 42, he established that laymen should not usurp clerical jurisdiction and clerics should respect lay rights. ${ }^{12}$ In canon 44, Cum laicis,

\footnotetext{
${ }^{9}$ Henry died September 10, 1197. He had participated in the Third Crusade.

10 James A. Brundage, Medieval Canon Law and the Crusader (MadisonMilwaukee-London 1969) 78-81, 118. Innocent's 'decet, licet, expedit' that he most likely borrowed from Bernard of Clairvaux, De consideratione 3.4.15, became a touchstone for making decisions and its principles were carried over into many other areas of law; see e.g. Brian Tierney, 'Hostiensis and Collegiality', Proceedings Toronto $1972401-409$ at 405 citing Hostiensis to X 3.10.4 or Antonio Augustin, Opera omnia (Vol. 2; Lucca 1766) 446 to his commentary on Justinian's 'De regulis iuris' 186 (recte 144).

${ }^{11}$ E.g. Emanuele González Téllez, Commentaria perpetua (Venice 1766) to X 3.34.7 fol. 431: 'ex causa episcopum votum emisisse. . . ut de libertate ecclesiae Trecensis ageret cum comite Campaniae'.

12 Antonio García y García, ed. Constitutiones Concilii quarti Lateranensis una cum Commentariis glossatorum (MIC Series A: Corpus Glossatorum 2; Città del Vaticano 1981) 82-83. Canon 42 was not accepted into the body of canon law: 'Quod circa universis clericis interdicimus ne quis pretextu ecclesiastice libertatis suam de cetero iurisdictionem extendat in preiudicium iusticie secularis'.
} 
Innocent proclaimed a fundamental principle of ecclesiastical liberty: the property of churches could not be alienated by laymen. Fiefs possessed by a church or all other ecclesiastical properties were immune from lay power. ${ }^{13}$

The old issue of immunity of clerics from lay judicial power also raised the theme of ecclesiastical liberty. A decretal of Pope Honorius III dealt with Hildebrand, bishop of Fiesole, who had been condemned and banned from Florence by a Florentine court even though the court had not followed the strict rules of judicial procedure when it summoned witnesses outside of the courtroom. ${ }^{14}$ For that violation of judicial procedure, Honorius revoked the secular court's decision and fined Florence 1000 pounds for damaging ecclesiastical liberty. ${ }^{15}$ As Bernardus Parmensis pointed out in his Ordinary Gloss a secular judge may not burden a cleric 'with his law' and must therefore be considered to have committed a sacrilege and violated ecclesiastical liberty. Because of his sacrilege he had been condemned to a monetary fine. ${ }^{16}$ Although the facts of the case were complicated, the principle was clear: secular rulers and courts had no jurisdiction over clerics.

Pope Gregory IX rendered a decision that laymen were forbidden to participate in elections held in collegiate churches. Gregory declared that even if a lay patron, the prelate, and the chapter of the church agreed that the patron could elect a member of the chapter, that agreement was not valid. A layman should not possess the right of election because it would be a pernicious

134 Comp. 3.5.1 (X 3.13.12). See also Maria Pia Alberzoni, 'Innocenzo III e la defesa della "libertas ecclesiastica" nei comuni dell'Italia settentrionale', Innocenzo III: Urbs et orbis: Atti del congresso internazionale, ed. Andrea Sommerlechner (2 vols. Nuovi studi storici 55; Rome 2003) 2.837-928, at 838839.

${ }^{14} 5$ Comp. 5.11.1 (X 5.36.7).

15 At the Council of Vienne Pope Clement V again condemned the practice of subjecting clergy to the ban in secular courts, Clem. 5.8.1. See Peter R. Pazzaglini, The Criminal Ban of the Sienese Commune 1225-1310 (Quaderni di 'Studi senesi' 45; Milan 1979) and Christian Zendri, Banniti nostri temporis: Studi su bando e consuetudine nel diritto comune (Collana della Facoltà di Giurisprudenza dell’Università degli Studi di Trento 9; Napoli 2016).

${ }^{16}$ Bernardus Parmensis, Ordinary Gloss to X 5.36.7 s.v. banniuerit. 
example and a loss of ecclesiastical liberty. ${ }^{17}$ Previous canon law gave a patron the right to select a cleric in a church in which he had a right of election (ius eligendi). Later canonists explained this contradiction by distinguishing between the right to present a candidate and the right to elect. ${ }^{18}$

A significant piece of legislation governing ecclesiastical liberty in the Corpus iuris canonici was a mandate of Pope Nicholas III in 1280 that he promulgated as a general constitution to the entire church. It was later included in Boniface VIII's Liber sextus. ${ }^{19}$ At issue was the common practice of swearing oaths to uphold the statutes and customs in both the ecclesiastical and secular polities by clerics and secular magistrates. Nicholas warned them both that when they take such oaths they should always swear that they except all things that are 'illicit, impossible, or contrary to ecclesiastical liberty'. ${ }^{20}$ Johannes Andreae made two points when he discussed the decretal. First the magistrates in charge of promulgating statutes (statutarii) who publish statutes contrary to ecclesiastical liberty will be excommunicated if they do not delete the offending statutes within two months, ${ }^{21}$ and second, the jurisprudence of the Ius commune should regulate all oaths. $^{22}$ That jurisprudence clearly established that oaths cannot bind those who do not know that what they swear to is contrary to

${ }^{17}$ X 1.6 .51 (ca. 1227-1234).

${ }^{18}$ See the Ordinary Gloss on X 1.6.51 s.v. in laicum and, much later, Emanuele Gonzalez Tellez, Commentaria (Venice 1766) vol. 1, pp.. 224-225. On 'Ius patronatus' see the fundamental work of Peter Landau, Ius patronatus: Studien zur Entwicklung des Patronats im Dekretalenrecht und der Kanonistik des 12. und 13. Jahrhunderts (Köln-Wien 1975).

${ }^{19}$ VI 2.11.1, Contingit in nonullis ecclesiis, which was printed from an original bull sent to Lübeck, Codex diplomaticus lubecensis, ed. Wilhelm Leverkus (2 vols. Oldenburg 1856) 1.267-268.

${ }^{20}$ Ibid. 267 'qualitercumque et sub quacumque uerborum forma prestita uel prestanda ad licita possibilia et libertati ecclesiastice non obuiantia tantum extendi'.

${ }^{21}$ Johannes Andreae, Ordinary Gloss (Venice 1476) to VI 2.11.1 s.v. libertati.

${ }^{22}$ Ibid. s.v. Declaramus: 'Posito tamen quod in genere iuret: fit tamen secundum ius commune interpretatio iuramenti, et probatur hoc satis per decretalem supra eodem Ad nostrum iii. (X 2.24.21) et supra de verb. sign. Super quibusdam (X 5.40.26)'. 
law. ${ }^{23}$ Guido de Baysio summed up what constituted 'libertas ecclesiastica' in a gloss to the same decretal with a quotation taken from Pope Innocent IV: ${ }^{24}$

Ecclesiastical liberty is contained in privileges in spiritualities and in privileges in temporalities. Again it is found in general privileges granted to the church and in each privilege granted to individual churches.

Innocent had listed a number of ecclesiastical liberties in his commentary on the Decretals of Gregory IX: especially the church's freedom to collect tithes, first fruits, and offerings. He repeated the well-established principle that only the clergy can exercise authority over the church, and forbade violence against clerics. Innocent noted that ecclesiastical liberty permitted the clergy to make testaments with only two witnesses. ${ }^{25}$

Another striking instance of papal legislation occurred in a decretal included in the Liber sextus. Pope Boniface VIII warned all lay lords that they should never forbid their subjects from selling to or buying goods from clerics or ecclesiastical persons. If they presumed to do so, they would damage ecclesiastical liberty and would be punished with excommunication. ${ }^{26}$ Johannes Andreae pointed out this is an unusual infringement of ecclesiastical liberty but can be explained by understanding that the decretal forbade indirect fraud between persons. He gave the example that if one prohibited the transport of material for repairing a road, one prohibited the repair and indirectly the right to repair. ${ }^{27} \mathrm{He}$ noted that the Italian city states often promulgated

${ }^{23}$ Ibid. 'aut nesciebat $<$ statuta illicita $>$ nec id in mente gerebat. Et tunc non peccavit et solum ad licita obligatur'.

${ }^{24}$ Guido de Baysio, Apparatus ad Sextum (Milan 1490) to VI 2.11.1 s.v. ecclesiastice libertati: 'quod ecclesiastica libertas consistit in privilegiis super spiritualibus et in privilegiis super temporalibus. Item consistit in privilegiis generalibus ecclesie concessis et in privilegiis singularibus concessis cuique ecclesie quod prosequere, ut plene notatur Innocentius in predicto capitulo Noverit (X 5.39.49)'.

${ }^{25}$ Innocent IV, Commentaria (Venice 1495) to X 5.39.49 s.v. libertatem.

${ }^{26}$ VI 3.23.5.

${ }^{27}$ Johannes Andreae, Ordinary Gloss (Venice 1476) to VI 3.23.5 s.v. libertatis, the repairing of a road example is given in an addition to his text in his Ordinary Gloss (Basel: 1500); see my essay 'Johannes Andreae's Additiones to the 
statutes that restricted the buying or donating of goods that were given to ecclesiastical institutions.

'Libertas ecclesiastica' also attracted the attention of jurists outside the Corpus iuris canonici. The earliest treatise on 'libertas ecclesiastica' that I have found was written by a Portuguese jurist, Egas, a canon of the cathedral of Viseu who became its bishop in 1288 and died in $1313 .^{28}$ His tract did not circulate widely. It is preserved in five Iberian manuscripts. ${ }^{29}$ He probably wrote it ca. $1300:^{30}$

Because we talk about ecclesiastical liberty frequently, let's see what it is and how we can define it and what the penalties are for those who violate it. Ecclesiastical liberty is the immunity of ecclesiastical persons, places and property established by the holy fathers and the Catholic princes. This definition has been established by the Fourth Lateran Council's canon Cum laicis (c. $44=$ X 3.13.12).

Egas was most concerned about violence against clergy as attacking a fundamental ecclesiastical liberty. A text from the Second Lateran Council (1139) that Gratian included in his Decretum laid down the norm: if a person attacked a cleric he was ipso facto excommunicated. Only the pope could absolve the perpetrator. $^{31}$ Egas added a number of reasons, people, and

Decretals of Gregory IX', ZRG Kan. Abt. 74 (1988) 328-347 at 346-347; Johannes expanded his commentary on this decretal in his Novella in Sextum (Lyon: 1550) fol. 99rab, where he noted Italian legislation: 'Sepe in Italia interdicitur per statuta civitatum vel dominorum ne quis vendat vel donet rem immobilem alicui non existenti de iurisdictione statuentium vel non subeunti onera communium vel dominorum, et irritant venditionem et donationem, et infligunt penam ante, scilicet. includantur venditiones vel donationes in ecclesiam'.

${ }^{28}$ Antonio García y García, Estudios sobre la canonistica portuguesa medieval (Monografias 29; Madrid 1976) 126-127.

${ }^{29}$ Ibid. 249-255.

${ }^{30}$ Ibid. 257. See also Paulette L. Pepin, 'The Council of Peñafiel 1302: The Castilian Church's Reassertion of its libertas ecclesiastica', On the Social Origins of Medieval Institutions: Essays in Honor of Joseph F. O'Callaghan, ed. Donald J. Kagay (The Medieval Mediterranean 19; Leiden-Boston 1998) 243-262, who gives some context to the Iberian situation that Egas was addressing.

${ }^{31}$ Richard H. Helmholz, "Si quis suadente" (C.17 q.4 c.29): Theory and practice', ed. Peter Linehan Proceedings Cambridge 1984 426-438, discusses 
grounds not covered explicitly by the canon for imposing a ban of excommunication on violators of all sorts: If a person could have defended a cleric and did not. The person who ordered attack. People who kicked, poured water, or tore the clothing of clerics. If someone locked clerics in their home and would not let them out. ${ }^{32}$

Egas added many other cases when ecclesiastical liberty was violated. Many of his examples were drawn from the decretals that we have just discussed. He added a few interesting cases. If men violated a female cleric who wore a habit, they and any other participants in the crime will have their goods confiscated. The goods will be bestowed on the monastery of the victim. ${ }^{33}$ Further, perpetrators will be condemned to death. He also laid down the norms governing sanctuary, which had become a principle of ecclesiastical liberty. Churches, monasteries, and their cemeteries could provide immunity to free persons or slaves if they fear death or torture. They cannot be taken from these places unless they were public and well-known criminals. ${ }^{34}$

There seems to have been a hiatus between Egas' monograph and the tracts of jurists who began to explore 'libertas ecclesiastica' intensively during the last quarter of the fifteenth century. This monographic literature burgeoned into a substantial series of texts that defended clerics and churches from secular authorities until well into the eighteenth century. ${ }^{35}$ The first

the first comprehensive canon on lay violence against the clergy at the Second Lateran Council, c. 15 in modern editions.

32 García y García, Estudios 258-259.

33 Ibid. 262.

${ }^{34}$ Ibid. 268. See Karl Blaine Shoemaker, Sanctuary and Crime in the Middle Ages: 400-1500 (Just Ideas: Transfomative Ideals of Justice in Ethical and Political Thought (New York 2011) and William Chester Jordan, 'A Fresh Look at Medieval Sanctuary', Law and the Illicit in Medieval Europe edd. Ruth Mazo Karras, Joel B. Kaye, Ann Matter (The Middle Ages; Philadelphia 2008) 1-6.

${ }^{35}$ Perhaps one of the most important of these texts was Alessandro Ambrosini's (ca. 1608), who wrote a detailed commentary on a decretal of Pope Gregory XIV, Commentaria in bullam Gregorii XIV De immunitate et libertate ecclesiastica (Parma 1608, reprinted in 1612 and 1621). I have not found any literature on Ambrosini even though he also published cases that were heard in the episcopal court of Perugia, Decisiones fori episcopalis perusini (Venice 1610). 
printed tract on 'Libertas ecclesiastica' was probably written by Heinrich Urdemann (ca. 1420-†1485) in the form of a dialogue between Hugo, Cato, and Oliverius. ${ }^{36}$ It was printed for the first time in 1477 and seems to have become a popular tract since it was reprinted in 1478, 1479, 1482-1483, 1484-1488. Urdemann constructed a debate about ecclesiastical privileges that had been given to institutions in the small Belgian town of Tienen.

Nicholas $(\dagger 1480)$, bishop of Modruš in Croatia a few years later wrote a tract he entitled Defensio libertatis ecclesiasticae. ${ }^{37}$ Nicholas dedicated the tract to Cardinal Raffaello Riario and wrote it circa $1479 .{ }^{38}$ Later he willed his library to Pope Sixtus IV (1471 1484). ${ }^{39}$ In his tract Nicholas deplored the mistreatment of ecclesiastical prelates and praised popes who had fought (decertare) for ecclesiastical possessions, and especially Sixtus's deeds and his war against the Turks. ${ }^{40}$ He concluded his treatise with a section filled with fulsome praise for Sixtus' pontificate. ${ }^{41}$

Why was ecclesiastical liberty an important theme at the Fifth Lateran Council when earlier councils between Lateran IV and Lateran $\mathrm{V}$ had ignored the issue? An easy explanation of these changes would be the turmoil and anxieties about schism and heresies at the dawn of the Reformation. However, as Johannes Andreae noted, Catholic princes and governments could be just as troublesome for the Church as entrenched dissenters. Certainly, religious dissent in the early sixteenth century helped to shape the agenda at the Fifth Lateran Council. However, Catholic lay resistance to ecclesiastical authority had been prevalent in the

\footnotetext{
${ }^{36}$ Hubert Höing, 'Dr. jur. Heinrich Urdemann (ca. 1420-1485: Kurienprokurator, Offizial, Stiftsdechant und kaiserlicher Rat: Zur Karriere eines voreformatorischen Klerikers in Bocholt, Köln und Rom', Annalen des Historischen Vereins für den Niederrhein 218 (2015) 105-150.

37 Giovanni Mercati, 'Notizie varie sopra Niccolò Modrussiense', Opere minori, 4: 1917-1936 (Studi e testi 79; Città del Vaticano 1937) 205-267.

${ }^{38}$ Ibid. 207, 211 My thanks to Professor Antonin Kalous, University of Olomouc for drawing my attention to this tract and giving me his notes on Vat. lat. 8092, fol.1r-68r.

${ }^{39}$ Mercati, 'Notizie' 208-212; see Egmont Lee, Sixtus IV and Men of Letters (Temi e testi 26; Roma 1978) 115, 195.

${ }^{40}$ Vat. lat. 8092 , fol. 2r-5r, $14 \mathrm{v}$.

${ }^{41}$ Ibid. fol. 65 r- 68 r
} 
fifteenth century. Several fifteenth-century councils legislated against Catholic infringements of ecclesiastical liberties. ${ }^{42}$ Even so, as one wades through the canons and text of previous councils and the texts of canon law one could not foresee the vigorous emergence of the theme of ecclesiastical liberty at the Fifth Lateran Council.

The Pragmatic Sanction of Bourges was certainly one of the reasons, perhaps the primary reason, that was responsible for 'ecclesiastica libertas' becoming a prominent issue at Lateran V. A council of French clergy in Bourges gathered with the purpose of reforming the French church. The prelates and clergy drew upon the canons promulgated at the Council of Basel (1431-1438) as a source for their reforms. King Charles VII of France was pleased with the results and incorporated their decisions into a royal ordinance on July 7, 1438 that was entitled the Pragmatic Sanction of Bourges. When Pope Julius II summoned the Church to a council at the Lateran one of his primary preoccupations was the Pragmatic Sanction and its damage to ecclesiastical liberties.

Julius' distaste for the Pragmatic Sanction is palpable in the letter, Saluti gregis, that he addressed to the Council's fourth session on the $10^{\text {th }}$ of December 1512. ${ }^{43}$ The king's use of the term, 'pragmatica sanctio,' was a poke in the papal eye. The terminology evolved in late Roman law and defined a law that was issued to a public, not private, group or institution; in this case the ordinance was promulgated for the Kingdom of France. ${ }^{44}$ Julius complained that for a long time French prelates and noble laymen had infringed on the liberty and authority of the pope, the Roman church, and the sacred canons because of the Pragmatic Sanction. Although King Louis XI had revoked it, Julius did not consider the royal revocation enough because it had not been confirmed by French parlements. The pope posted his summons to the French

\footnotetext{
42 Council of Angers 1448 (secular legislation), Mansi 32.89-90; Council of Toledo (transitus [travel] and ecclesiastical property) 1471, Mansi 32.398-400; Council of Senones 1485 (rights), Mansi 32.409; Council of Magdeburg 1489 (protection from secular authorities), Mansi 32.458, 473.

${ }^{43}$ Fifth Lateran's proceedings are edited by Nelson H. Minnich, 'Concilium lateranense V 1512-1517', COGD 2.2.1317-1455 at 1349-1351.

44 Justinian, Codex 1.23.7.2 and passim.
} 
and his condemnation of the ordinance on the doors of the churches in Milan, Asti, and Pavia, because, as he explained, France was too dangerous for representatives of the pope. ${ }^{45}$

Four years later Pope Leo X returned to the issue of the Pragmatic Sanction on December 19, 1516 at the eleventh session of the Council. ${ }^{46}$ In Pastor aeternus Leo repeated Julius' condemnation and railed again against the ordinance's violation of ecclesiastical liberty. His letter then took another turn. Leo admitted that the summons posted on the doors of three Italian churches were not adequate legally. He had probably been told by his curial jurists that Julius' summons did not conform to the norms of canonical jurisprudence. A summons, the canonists had agreed for three centuries, could not be omitted under any circumstances because it was required by natural law. Leo explained that the prelates, clergy, monasteries, and chapters claimed various impediments that prevented their obedience. Leo and his jurists knew that their claims could not be ignored. Canonical jurisprudence forbade it. Leo claimed that after Julius' death the summons to the French were 'legitimately' repeated but gave no proof that they now conformed to canonical norms. ${ }^{47}$ Nonetheless, he annulled the Pragmatic Sanction. He noted that no council had been legitimately held in the seventy years since the Sanction had been promulgated. Consequently, the Fifth Lateran Council was the first opportunity the Church had to abrogate the decree. He based his authority to abrogate the Sanction on Pope Boniface VIII's decretal Unam sanctam. ${ }^{48} \mathrm{He}$ tempered his claim with the same caveat that the French Pope Clement V used to placate King Philip the Fair in 1306, a decretal with the incipit Meruit carissimi filii. ${ }^{49}$ Clement had assured Philip that Unam sanctam did not prejudice the relationship of the Kingdom of France to the Roman church. The relationship between the kingdom and Rome would remain the same as it had

\footnotetext{
${ }^{45}$ COGD 2.2.1349-1351 lines 625-631, 654-658.

${ }^{46}$ COGD 2.2.1434-1442.

${ }^{47}$ COGD 2.2.1436, lines3503-3504: 'citatio legitime executa'.

${ }^{48}$ Extravagantes communes 1.8.1.

${ }^{49}$ Extravagantes communes 5.7.2.
} 
been before Unam sanctam. Leo made the same promise. What did Clement's and now Leo's promise mean in the sixteenth century? We will never know because no canonist ever glossed Meruit. In any case, the Fifth Lateran Council was the first and the last council to cite Boniface's controversial decretal.

Leo closed his letter with a list of people and offices who would be subject to a major excommunication if they respected or adhered to the terms of the Pragmatic Sanction directly or indirectly. Ecclesiastical liberty was preserved. As Minnich's new edition of the Council's proceedings illustrates, Leo simultaneously issued the Concordat of Bologna to define the relationship between the papacy and France. ${ }^{50}$ At the end of his letter on the Concordat, Leo concluded that if there were any customs, statutes, or practices in the Kingdom of France that infringed upon ecclesiastical liberty, this agreement did not approve them. ${ }^{51}$

In session nine that was held on May 5, 1514, Pope Leo dealt with another important issue: the safety of ecclesiastics and others who travelled to the Council. The legal concept, safe conduct (salvusconductus) and freedom of passage seems to have been born in the customary law of Northern Europe and did not enter the Ius commune until the late fourteenth century. The term, salvusconductus did not exist in earlier Roman and canon law. ${ }^{52}$ The idea that all human beings should have the right to travel to any place they wished to go was very old. ${ }^{53}$ However, it had not been an issue for those who had been summoned to church councils or to secular representative assemblies. The Church had long struggled with lay princes who detained, captured, or

\footnotetext{
${ }^{50}$ COGD 12.2.408-1434.

${ }^{51}$ COGD 2.2.1429, lines 3264-3269.

${ }^{52}$ In a decretal of Pope Innocent III in 1205, the same concept is expressed as 'securus conductus', 3 Comp. 2.3.4 (X 2.6.4).

53 See Pennington, 'Sovereignty and Rights in Medieval and Early Modern Jurisprudence: Law and Norms without a State', Roman Law as Formative of Modern Legal Systems: Studies in Honour of Wiesław Litewski. Edd. J. Sondel, J. Reszczyński, and P. Ściślicki. (2 Volumes. Kraków 2003) 2.25-36 at 29-32.
} 
imprisoned papal legates travelling in their territories. ${ }^{54}$ In spite of these occasional difficulties, the idea of granting papal legates, bishops, or clerics a right of safe conduct seems never to have arisen. The issue of safe passages at Constance and Basel was not to protect ecclesiastical liberty but was a legal solution for bringing religious dissenters to the councils. Canonical norms dictated that they could not, as we have seen, be judged in absentia. The Emperor Sigismund gave John Hus a vaguely worded safe conduct for the Council of Constance. ${ }^{55}$ The Council of Basel gave safe conduct passes in their decrees to representatives from Bohemia and Constantinople to attend its sessions. ${ }^{56}$ Rather than being examples of ecclesiastical liberty, Constance and Basel were attempts to conform conciliar actions and proceedings to the strict norms of canonical procedure. Their cases could not be heard and decisions could not be rendered at the council without their presence.

The development of 'salvusconductus' seems to be an example of practice preceding theory. If we can trust the sources it was an important royal instrument from the twelfth century on in Northern Europe. A very early example of a safe conduct being given dates to 1189. Roger of Hoveden reported that Philip of Flanders granted King Richard of England a safe conduct to Calais. ${ }^{57}$ The records of the Tower of London record many safe conducts granted for various reasons in the early fourteenth century. The earliest is dated $1311 .^{58} \mathrm{John}$, the abbot of Cluny,

\footnotetext{
${ }^{54}$ Papal legates constantly faced secular violence in the period from 1000-1500, e.g. Trevor Dean, 'Rise of the signori', The New Cambridge Medieval History, c.1198- c.1300, ed. David Abulafia (Volume 5; Cambridge 1999) 459-460 and in other essays of the volume pp. 136, 387, 392 .

55 Thomas A. Fudge, The Trial of Jan Hus: Medieval Heresy and Criminal Procedure (Oxford 2013) 260, with the literature he cites.

${ }^{56}$ CODG 2.2778-782, 981-986.

57 Chronica Magistri Roger de Houedene, ed. William Stubbs (3 vols. Cambridge 2012) 3.28; see also 215, 244.

${ }^{58}$ Rotuli scotiae in turri londinensi et in domo capitulari westmonasteriensi asservari, 1: Temporibus regum Angliae Edwardi I. Edwardi II. Edwardi III. (London: 1814) 108, 120, 125, 127, and passim. The 'rotuli' records numerous examples from 1215 to the reign of King Henry V († 1422), see Mémoires de
} 
asked for a 'salvus conductus' for his monks who were to negotiate a contract with Sir Gilbert Talbot in Calais 1392. He asked that Talbot petition a safe conduct from King Richard II or from the governor of Calais. ${ }^{59}$ Baldus de Ubaldis $(\dagger 1400)$ is the earliest jurist known to me who used 'salvusconductus' in the legal literature of the Ius commune before Constance. In an undated consilium Baldus wrote about a case in which the city of Asti had issued a safe conduct to Thomas and Manfredus that they could enter the city with an armed retinue. Later Manfredus sent his wife into the city with another armed band of retainers. She was arrested and her followers' weapons and goods confiscated. Baldus wrote a consilium in the wife's defense and concluded that a safe conduct covered the wife citing primarily Roman law principles. ${ }^{60}$ Baldus' conclusion that a safe conduct covered wives was expanded in Lateran V's decree to include all members of a traveler's household. ${ }^{61}$ If Asti was issuing safe conducts, other Italian cities also were. In any case these documents and Baldus' consilium is evidence that the legal instrument for protecting litigants was fairly commonplace by 1400 .

The safe conduct that Pope Leo mandated in session nine at the Fifth Lateran opened a completely new legal issue. The safe conduct was no longer only a protection provided to litigants or travelers who could be arrested or imprisoned without one, it was also a benefit or a grace bestowed by the prince on his subjects. The Council of Trent granted safe conducts to German Protestants who wished to attend the Council. ${ }^{62}$ These safe conducts were not the same general grants of privilege that Lateran $\mathrm{V}$ had inaugurated. Later criminal jurists concentrated on defining safe

la Société des Antiquaires de la Normandie ( $2^{\text {nd }}$ Series, $5^{\text {th }}$ vol. Paris 1846$) 157$, 216-234 and passim.

${ }^{59}$ Charters and Records among the Archives of the Ancient Abbe of Cluni (sic), from 1077 to 1534, ed. G.F. Duckett (sine loco 1888) volume 1.135-136.

${ }^{60}$ BAV Barberini lat. 1406, fol. 5r-5v; printed in volume one of his consilia (Milan 1494) number 109 (unfoliated).

${ }^{61}$ Prospero Farinacci, Fragmentorum variorum quaestionum et communium opinionum criminalium pars secunda (Nüremberg ca. 1690) 90 number 607.

${ }^{62}$ Council of Trent, Session 15, January 25, 1552 and Session 18, February 26, 1562. 
conducts almost entirely as a part of criminal proceedings, especially connected to a summons to attend a trial. ${ }^{63}$ However, the safe conduct as a protection for legates, ambassadors, and travelers gradually evolved into diplomatic immunity that is a key element of international law today. ${ }^{64}$ Lateran $\mathrm{V}$ can take some credit for playing a part in that development.

In session nine, the problem of lay violence against the clergy was again broached. As we have seen, the Church had struggled with lay violence against clergy and against ecclesiastical property for centuries. ${ }^{65}$ It had been a key issue for ecclesiastical liberty since the twelfth century. During the Second Lateran Council of 1139 Pope Innocent II (1130-1143) promulgated Si quis suadente that was immediately incorporated into the last recension of Gratian's Decretum. ${ }^{66}$ Johannes Teutonicus, who wrote the Ordinary Gloss to the canon (ca. 1217), compiled a laundry list of exceptions to the norm that a layman could not attack a cleric. Self-defense was the most important. A layman could always justly defend himself against an attack by a cleric. A layman could attack a cleric if he found his wife, mother, sister or daughter in bed with a cleric. In those and other cases Johannes thought a layman could strike a cleric with impunity. ${ }^{67}$ Later jurists posed even more subtle questions. At the end of the thirteenth century Guido de Baysio asked if a layman should be excommunicated if

\footnotetext{
${ }^{63}$ The literature is extensive. See e.g. Marcantonio Savelli, Summa diversorum tractatuum (4 vols. Venice 1715) 4.73-76; Jacobus Menochius, De arbitrariis iudicum, quaestionibus et causis (Cologny 1630) 612-617 (consilia 436-437)

${ }^{64}$ See Albericus Gentilis, De iure belli libri tres, ed. Thomas Erskine Holland (Oxford 1877) 185-192 and Willem van der Meulen's extensive commentary on Grotius, Hugo Grotius, De iure belli ac pacis libri tres (Amsterdam 1704) 3.14, p.271; Montell Ogdon, 'The Growth of Purpose in the Law of Diplomatic Immunity', American Journal of International Law 31 (1937) 449-465; for a general history of the subject see Marsha L. Frey and Linda Frey, The History of Diplomatic Immunity (Columbus 1999). The legal background and sources of diplomatic immunity have not yet been studied.

${ }^{65}$ Richard H. Helmholz, The Canon Law and Ecclesiastical Jurisdiction from 597 to the 1640s (The Oxford History of the Laws of England, 1; Oxford 2004) 505-508 and his earlier study cited above.

66 Second Lateran c. $15=$ C. 17 q. 4 c. 29 .

${ }^{67}$ Johannes Teutonicus to C.17 q.4 c. 29 s.v. violentas manus.
} 
he seized a cleric's horse to escape his enemies by violently throwing him off it. Tancred of Bologna had thought the layman should be excommunicated, but his penalty should be milder and no penance should be imposed on him. Guido argued the layman had acted according to the law. He was under duress and in times of necessity all things were held in common. ${ }^{68}$

By the beginning of the sixteenth century clerical immunity from lay violence was embedded deeply in the jurisprudence of the Ius commune. The Fifth Lateran canon, Supernae dispositionis arbitrio expanded clerical immunity and ecclesiastical liberty. ${ }^{69}$ It renewed Pope Boniface VIII's decretal Felicis recordationis that dealt with violence against the cardinals and endorsed Pope Clement V's decretal, Si quis suadente diabolo, whose incipit echoed the beginning of the Second Lateran Council's canon, and which focused on violence against bishops. ${ }^{70}$ From a legal point of view, renewing these two older decretals was redundant. They had attracted extensive commentaries and had been long included in the Corpus iuris canonici. Leo emphasized that he wished to renovate all the papal decretals that had been issued in favor of ecclesiastical liberty. ${ }^{71}$ He especially mentioned In coena Domini as being important for punishing the violators of ecclesiastical liberties. $^{72}$

It may have been Leo's primary purpose to insert In coena Domini into conciliar legislation. The bull was a cornucopia of ecclesiastical liberties and privileges that had the protection of the pope. First published by Pope Urban V in 1363, it was republished by Gregory XI (1372), Martin V (1420), and by Julius II just

${ }^{68}$ Guido de Baysio, Rosarium (Venice 1480 ) to C.17 q.4 c.29 unfoliated: 'Si quis nam necessitatis tempore debent omnia esse communia, xlvii. di. Sicut hi (c.8). preterea iste fecit ob tutelam corporis sui, ergo videtur iure fecisse. Ergo non dicitur fecisse diabolo suadente'. On the concept of 'communis omnium possessio', see Brian Tierney, The Idea of Natural Rights: Studies on Natural Rights, Natural Law and Church Law 1150-1625 (Emory University Studies in Law and Religion. Atlanta, Georgia 1997) 69-76.

${ }^{69}$ COGD 2.2.1389-1390.

${ }^{70}$ VI 5.9.5 and Clementines 5.8.1.

${ }^{71}$ COGD 2.2.1389, line 1999.

${ }^{72}$ Ibid. line 2001. 
before he opened the Fifth Lateran Council. Although it had been published regularly by previous popes, the decree had never been incorporated into canon law. Pope Leo must have wanted its provisions to be a part of papal conciliar legislation. Besides renewing Felicis recordationis and Si quis suadente, the Fifth Lateran's canon also contained other ecclesiastical privileges. Secular authorities were forbidden to impose financial burdens on prelates and clerics and should not receive any contributions even if the clergy consented to the payment. If prelates consent to these financial payments they will be excommunicated and removed from office. Henceforth they were rendered incapable of any legal act and could not make a will.

A few years later Leo promulgated his version of In coena Domini in 1517. His list of ecclesiastical liberties for the clergy and prelates was extensive. He excommunicated those who impeded food destined for Rome and the Roman Curia and those who robbed, detained, abused, mutilated, or killed persons' exercising their offices in the Curia. Those persons who mutilated, wounded, killed, captured or detained patriarchs, archbishops, bishops were also excommunicated. He also excommunicated those who abused, mutilated, killed, or despoiled ecclesiastical or secular persons who had come to the Roman Curia to prosecute their cases. Their advocates, procurators, judges, or their delegates were also taken under the protection of the bull. The same protection was given to pilgrims who came to Rome. Like Lateran II's provision, these excommunications could only be lifted by the pope. ${ }^{73}$ Leo's bull repeated previous provisions of In coena Domini, but he clearly intended that the bull should circulate widely. The printing press was an effective vehicle. For the first time in the history of this papal bull, Pope Leo had it printed in Rome during April of $1517 .{ }^{74}$ The reissuing of In coena Domini continued until Pope Clement XIV stopped reaffirming its publication in 1770 because of opposition from Catholics and Protestants.

\footnotetext{
${ }^{73}$ Ibid. [pp.2-4] unpaginated.

74 Bulla in cena Domini (Rome apud Iacobum Mazochium M.D.XVII. Die ix.Aprilis).
} 
In the tenth session on May 4, 1515, the Council dealt with the issues of ecclesiastical exemptions for individuals and institutions, especially the exemptions from episcopal jurisdiction over monastic foundations and clerical crimes. ${ }^{75}$ Bernard de' Rossi, bishop of Treviso, stepped up to the pulpit and read Leo's canon, Regimini universalis ecclesiae. ${ }^{76}$ The letter was a very mixed message about ecclesiastical liberty. Bernard declared that the pope had discovered many reports of canons' having made claims of exemptions in various churches, secular and regular, from episcopal jurisdiction. Under the cloak of immunity from episcopal jurisdiction, clerics had, however, committed crimes because they did not fear episcopal discipline. Their crimes created scandal. These criminal clerics who had papal exemptions should be punished by delegated authorities, but if these papal delegates neglected their duties the local ordinaries may intervene after proper legal warnings had been given publicly. ${ }^{77}$

The local bishops were given ambiguous instructions. They could proceed through the inquisitorial or the accusatorial modes of proof. They could not, however, use torture in their proceedings. They could examine the accused in person. All the testimony should be sealed and nothing should be made public, unless there was a complaint that a proper summons had not be served. The written documents should then be sent to Rome at the expense of the defendants. ${ }^{78}$ Leo concluded by informing the local ordinaries that if the defendants were found to be guilty or if there

75 This is an issue with a long history of canonical jurisprudence; see Pennington, Pope and Bishops: The Papal Monarchy in the Twelfth and Thirteenth Centuries (The Middle Ages; Philadelphia: 1984) 154-189 especially at 177-186.

${ }^{76}$ Sacrum lateranense concilium novissimum sub Iulio ii et Leone x celebratum, ed. Antonio Maria Ciocchi del Monte (Rome 1520) fol. 147v: 'Deinde reverendus pater Dominus Bernardus Episcopus Taruisinus ascendit ambonem et legit contra exemptos cedulam et alias materias ecclesiasticam libertatem et dignitatem episcopalem concernentes cuius tenor talis est'.

${ }^{77}$ COGD 2.2.1394-1400 at 1394-1395.

${ }^{78}$ COGD 1395-1396 lines 2208-2223. 
were sufficient evidence to torture them to discover the truth, the local ordinary may render a decision according to what was just. ${ }^{79}$

This was the first and only time that a papal council mandated or even mentioned torture. No council had ever declared that torture was a permissible procedure in ecclesiastical courts. Although ecclesiastical courts were not permitted to use severe forms of torture, there was a growing acceptance of the milder forms of torture in the inquisitions into heresy and in some other criminal cases. ${ }^{80}$ There is some visual evidence that episcopal courts used torture in the fourteenth century. In a Decretum manuscript ca. 1300 that was produced in Southern France, there is a vivid illumination of a bishop conducting the torture on a tonsured cleric with a method of torture known as La corda (Figure 1). ${ }^{81}$ The torturer wears a lay person's hat. A cleric is shown being tortured. The division of the illumination into two spaces seems to imply that the judicial process took place in the episcopal court, while the cleric was tortured outside it. There are other Gratian manuscripts that illustrate the similar scenes. ${ }^{82}$ All the images employ La corda, which was the most commonly used form of torture in the judicial forum. We do not yet have studies

\footnotetext{
${ }^{79}$ Ibid. lines 2220-2222.

80 See Henry Ansgar Kelly, 'Judicial Torture in Canon Law and Church Tribunals: From Gratian to Galileo', CHR 101 (2015) 754-793, argues that torture was used in ecclesiastical courts, especially in the case of heresy but also for other crimes in the fourteenth century on. He presents no evidence on its frequency but relies on inquisitorial manuals.

${ }^{81}$ On La corda see Pennington, 'Women on the Rack: Torture and Gender in the Ius commune', Recto ordine procedit magister: Liber amicorum E.C. Coppens, edited by Jan Hallebeek, Louis Berkvens, Georges Martyn, and Paul Nève (Iuris Scripta Historica 28; Brussels 1212) 243-257 at 249.

${ }^{82}$ Avignon, Bibliothèque de la ville 659, fol. 189v; Berlin, Staatsbibliothek, lat. Fol. 4, fol. 176r, Berlin, Staatsbibliothek Ham. 279, fol. 99v, Escorial, Real Biblioteca del Escorial, ç.I.4, fol. 205v. a London manuscript in private ownership, see Maria Alessandra Bilotta, 'Le Décret de Gratien: Un manuscript de droit canonique toulousain reconstitué', Art de'l'emluminure 24 (2008) 10, 40-41. Joanna Fronska and I are writing an essay on these illuminations.
} 
exploring the frequency of torture in ecclesiastical courts. ${ }^{83} \mathrm{We}$ do know that secular courts employed torture infrequently. ${ }^{84}$

Regimini universalis ecclesiae begs for interpretation. There was no existing jurisprudence in canon law that might have answered basic questions that the canon raised, e.g. which crimes fell under the canon and which clergy could be summoned are only the most elementary. There was a lot of jurisprudence on other questions. What type of evidence was necessary before a defendant could be tortured? Was 'sufficientia indicia,' the terminology of Regimini universalis ecclesiae, different from the more standard terminology, 'vehementes, indubitata, manifesta indicia?' We will never know the answers to those questions because the council forbade every Christian from glossing and interpretation of the canons without papal approval under the penalty of automatic excommunication. ${ }^{85}$ This prohibition was unprecedented. Not since Justinian had any ruler forbidden jurists to interpret legal texts. ${ }^{86}$

At the end of Regimini universalis ecclesiae Leo turned from the rights of prelates and returned to the issue of ecclesiastical liberty of clerics. ${ }^{87}$ Leo declared that no power (facultas) had been given to laymen that they might exercise over clerics or over ecclesiastical property. He renewed all the constitutions in the Corpus iuris canonici that dealt with tithes, plunders of ecclesiastical property, arsonists, pillagers of fields, laymen who seize cardinals, bishops, and other clerics, or anyone who took away the jurisdiction rights of clerics. He emphasized that laymen

${ }^{83}$ A court case in Perugia raised the question whether a cleric should be tortured in a case in which he had claimed self-defense. The argumentation in the case presumed that if the evidence were adequate, the cleric could be tortured. However, it is not clear from the decision if the cleric was in orders. See Decisiones fori episcopalis perusini 265-271.

${ }^{84}$ Pennington, 'Torture and Fear: Enemies of Justice', RIDC 19 (2008) 203242. My thanks to Joanna Fronska for her comments on these illuminations.

${ }^{85}$ Session 12, March 16, 1517, COGD 2.2.1453 lines 4086-4089.

${ }^{86}$ With the exception of Pope Nicholas III who forbade that his constitution Exiit qui seminat (VI 5.12.3) be glossed; his prohibition was abrogated a short time later by Pope John XXII. See also Sinisi, 'Tridentine Decrees' 211-212 227-228 et passim below in this volume.

${ }^{87}$ COGD 2.2.1398-1399, lines 2303-2335. 
should have no rights to compel or interfere with the bestowing of ecclesiastical benefices. All of these crimes damage ecclesiastical liberty. Therefore the pope ordered all secular rulers to obey these constitutions and to command their subjects to do the same. Any contrary customs were void. Leo's list of offences and references to earlier canonical norms would have given the teachers of canon law much to discuss if they had been permitted to do so.

What conclusions can be drawn from this evidence about the Fifth Lateran Council and its fostering of ecclesiastical liberties? Giuseppe Alberigo's short introduction to his edition of the Council's canons does not make any claims for its importance. In his introduction to the latest edition of the canons, Nelson Minnich points out that the abrogation of the Pragmatic Sanction of Bourges was Leo's success. However, he also notes that most bishops opposed the council's closure. They thought the work of the Council was not done. Minnich observes that Trent followed Lateran $\mathrm{V}$ by not permitting its canons to be glossed. ${ }^{88}$ This prohibition led to a crucial change in the status and importance of the schools of canon law. From the point of view of a historian of canon law, Lateran V and its pedisequus Trent, were responsible for diminishing the importance of canonical jurisprudence as a source of law and as a source of norms and principles in the Church. It is not by chance that the last collection of papal decretals was published before Lateran V. All attempts to compile collections of papal legislation after Lateran $\mathrm{V}$ failed. Various jurists worked on a Liber Septimus of decretals. ${ }^{89}$ Their efforts were not successful. These collections included canons from Lateran $\mathrm{V}$ and from Trent. That may be one reason for their

${ }^{88}$ COGD 2.2.1453, lines 4088 and Minnich's Introduction to his edition of the canons in CODG 2.2.1324.

89 Elisabeth Dickerhoff-Borello, Ein Liber Septimus für das Corpus iuris canonici: Der Versuch einer nachtridentinischen Kompilation (Forschungen zur kirchlichen Rechtsgeschichte und zum Kirchenrecht 27; Köln-WeimarWien 2002) and Lorenzo Sinisi, Oltre il Corpus iuris canonici: Iniziative manualistiche e progetti di nuove compilazioni in età post-tridentina (Collana della Facoltà di Giurisprudenza dell'Università degli Studi Magna Graecia di Catanzaro; Soveria Mannelli 2009). 
failure. ${ }^{90}$ In any case, Leo X's and Pope Pius IV's prohibitions against commentary and glossing of conciliar canons cast a pall over the future of canonistic jurisprudence. The damage has lasted for centuries. Creative canonical jurisprudence died as a source of law within the Church and as an influential system of jurisprudence outside it. It would take another essay to defend that last generalization. Its truth can be found in the scholarship of the last fifty years in which scholars have illustrated in great detail the importance of canonical jurisprudence for shaping the Ius commune, which in turn has formed the bedrock of modern jurisprudence. ${ }^{91}$

The Catholic University of America

${ }^{90}$ Dickerhoff-Borello, Liber Septimus 235-242, whose conclusions about the 'Interpretationsverbot' are opaque.

91 The list of scholars who have contributed to exploring and illustrating the importance of medieval canonical jurisprudence for shaping modern law is very long. To mention only a few names: Brian Tierney, Richard Helmholz, Ennio Cortese, Jean Gaudemet, Walter Ullmann, James Muldoon, John T. Noonan, Jr. Peter Landau and many others. 


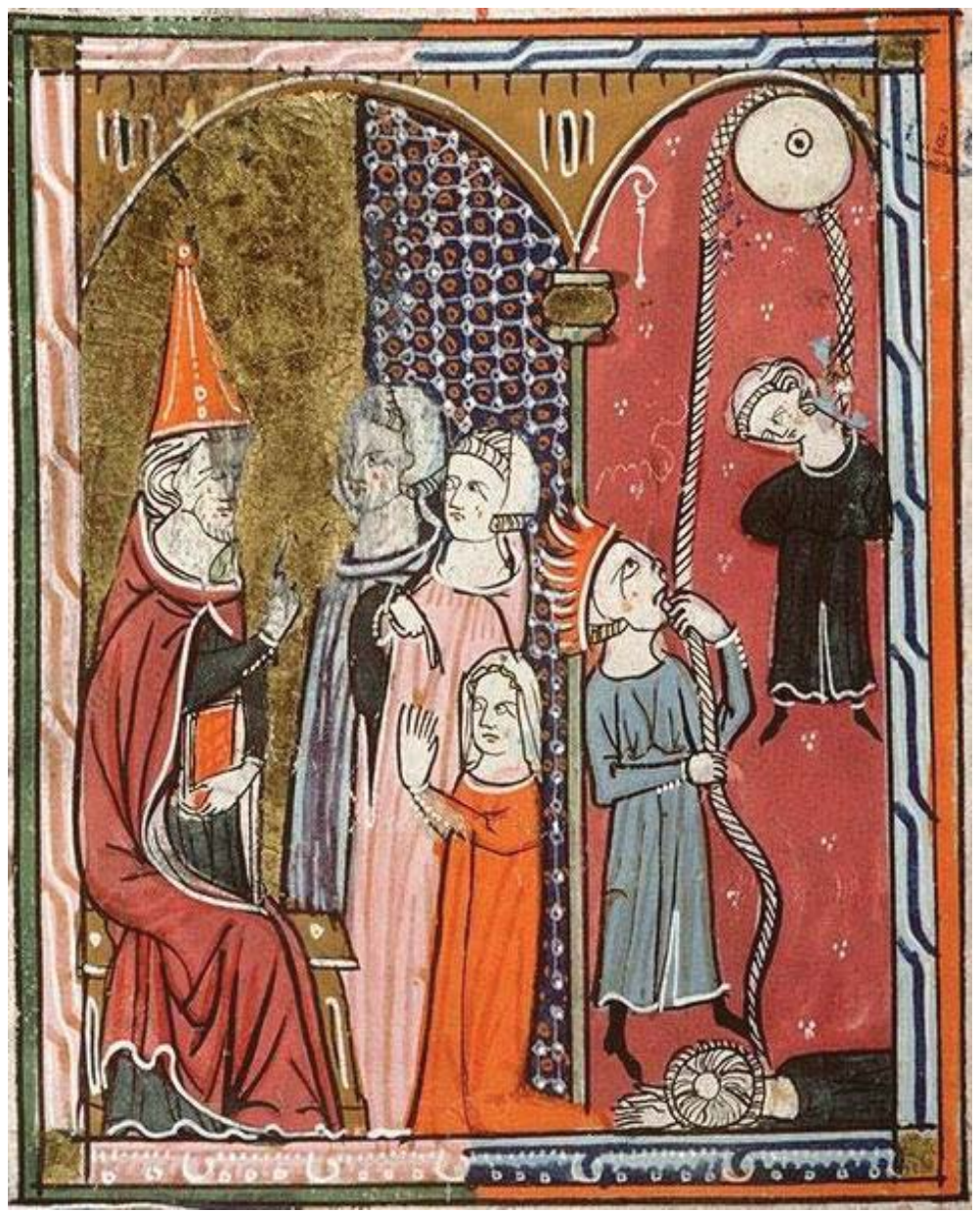

Figure 1. Gratian, Decretum C.15,

Amiens, Bibliothèque municipale 355, fol. 208v 